scientific work will be pursued, including the study of glacier systems.

The iron steamer Mfiranda, chartered by Dr. Frederick A. Cook, of Brooklyn, sailed from New York the same afternoon with a party of fifty men of science and pleasure-seekers. Labrador and the west coast of Greenland will be visited. Several of the party will remain in Greenland to prosecute scientific researches. The steamer will then go to Melville Bay, and perhaps visit the quarters of Peary and other explorers, returning about the middle of September.

Among the passengers were ten Eskimo, who had been stationed in the Eskimo camp at the World's Fair in Chicago last year, and are returning home.

Brooklyn.

\section{Rearing of Plaice.}

IN NATURE of July 12 (p. 251), there is an interesting note on the rearing of larval plaice at Plymouth, by MIr. $j$. T. Cunningham, in which it is mentioned that they have been reared to the age of thirty-seven days ; but it is not stated how long the incubation went on. It may be interesting to say that at the Fishery Board's Marine Hatchery, at Dunbar, I succeeded in preserving many millions of larval plaice from twenty-four to thirty-three days, counting from the time of fertilisation; and some were reared in jars for longer. On one occasion $I$ kept them in a thriving condition to the forty-seventh day after im. pregnation of the eggs, at which age they were carried away by an accidental overflow. The eggs were fertilised on April 3, hatched on April 19, and larva reared until Mray 20, when the accident occurred. $A$ description in full will be given in the Fishery Board's report. Harald Dannevig.

Fishery Board's Marine Hatchery, Dunbar, July 17.

\section{Absence of Butterflies.}

Referring to "Delta's" note, I may say that in the fine weather which we had here in April, the small tortoise-shell butterfly appcared more numerously than ever I had witnessed it at that season, or indeed at any time. I recollect counting a dozen at one time on a small bush of Antromeda floribunda, then in flower. Many of them were on wing in the latter days of March, alighting on the willow blossoms. With the fall of temperature in May they disappeared, and only in these recent warm days of July have I again seen them. The first white butterfly of the season was seen here April $2 \mathrm{t}$, the glowworm on June 23 (three weeks later than last year), and the horse-fly, Hippo. bosca equina, on June 28 .

Tynron, Dumfriesshire. J. SHAw.

\section{THE OXFORD MEETING OF THE BRITISH ASSOCIATION.}

$W^{E}$ regret to announce that Mr. W. H. White, C.B., will be unable, through ill-health, to give the evening lecture on "Steam Navigation at High Speeds," announced for Thursday, August 9. The Council of the Association has secured the services of Dr. J. W. Gregory to fill his place, and we believe that the title of Dr. Gregory's lecture will be "Experiences and Prospects of African Exploration."

During the past week further information has come to hand as to the work in some of the Sections. In Section C (Geology) the President, Dr. L. Fletcher, will deal in his address with the progress of mineralogy since Dr. Whewell's report was presented in 1832 . Prof. Green will read a paper on the geology of the country round Oxford, with special reference to the places to be visited during the excursions. Prof. Boyd Dawkins will contribute several papers, including one on the probable range of Coal Measures under the newer rocks of Oxfordshire. Amongst others are papers by Mr. H. A. IIiers, on a new method of measuring crystals; by MIr. E. P. Culverwell, on an examination of Croll's and Ball's theory of Ice Ages and Glacial Epochs; Mr. W. W. Watts, on barytes in Keuper sandstone; Dr. H. Hicks, on some Lacustrine deposits of the Glacial Period in Middlesex; and Dr. J. Anderson, on some volcanic subsidences in the North of Iceland. There will be a joint meeting of Sections $\mathrm{C}$ and $\mathrm{H}$, to discuss the implements of the plateau gravels and their bearing on the antiquity of man.

In Section G (Mlechanical Science), the President, Prof. A. B. W. Kennedy, will deal in his address with modern mechanical training, constructive and critical. Sir Frederick Bramwell will read a paper on Thursday, August 9, on Steam Locomotion on Common Roads. On the Friday there is to be a joint discussion with Section $\mathrm{A}$, on Integrators, Harmonic Analysers, and Integraphs, and their applications to physical and engineering problems. This discussion will be opened by Prof. $O$. Henrici, who is expected to exhibit some valuable models and instruments. On the same day, Lord Kelvin will read a paper on the resistance experienced by solids moving through fluids, which will be followed by a discussion on Flight. Other papers, by Prof. Fuller, MIr. FitzMaurice, and Mr. H. Daver, will follow. On the Saturday, Sir A. Noble, F.R.S., will open with a valuable paper on the measurement of pressures in gun bores; and other papers, by MIr. B. Donkin and Mr. J. Kenwood, will follow. The MIonday will be devoted to electrical questions, and among others Mr. W. H. Preece will give two papers on Signalling without Wires, and on the Efficiency of Glow Lamps. On the Tuesday, several papers of mechanical engineering interest will be read by Prof. Unwin, Mr. J. Swinburne, Prof. Capper, and Prof. Hudson Beare.

The programme of Section $\mathrm{H}$ (Anthropology) is already a large one, including nearly fifty reports and papers of great interest. Amongst these are papers by Mr. Lionel Decle, on the native tribes of Africa betwcen the Zambesi and Uganda; Dr. A. B. Meyer, on the distribution of the Negritos; M. Enile Cartailhac, on the art and industry of the Troglodytes of Bruniquel (France), and two other communications; Mrr. J. Theodore Bent, on the natives of the Hydramoot; Count Goblet d'Alviella, on recent discoveries in prehistoric archæology in Belgium ; Prof. MIax Lohest, on observations relative to the antiquity of man in Belgium; Mr. Arthur Evans, on the discovery of a new hieroglyphic system and pre-Phœnician script in Crete ; and Prof. J.Kollmann, on pygmies in Europe. It must be understood that where dates have been given above, they are only provisional, and that the order in which the papers are to be read is liable to alteration before and during the meeting, due notice of which will be given in the daily journal.

Section I (Physiology) will meet in the fine Physiological Laboratory of the University adjoining the Museum ; and, judging from the number and interesting character of the communications which have been already promised, its launch into independent existence should prove most successful. A very large number of the physiologists of Great Britain have announced their intention of being present, and, in addition, the President of the Section, Prof. Schäfer, will have the support of several distinguished foreign physiologists, amongst whom are Prof. Chauveau (of Paris), Prof. Hermann (of Königsberg), Prof. Engelmann (of Utrecht), Prof. Heger (of Brussels), and Prof. Gaule (of Zurich).

The programme of local arrangements is drawn up, but owing to alterations being required, consequent on the withdrawal of MIr. W. H. White's lecture, and other causes, it will not be ready for distribution before the beginning of next week.

The Local Secretaries desire to give notice that all communications should be addressed to them at the British Association Office, the Examination Schools, Oxford, and not to the University MIuseum, as heretofore.

NO. I 291 , VOL. 50] 